удК 347.1

Ю. В. Виниченко

Байкальский государственный университет, 2. Иркутск, Российская Федеращия

\title{
СОСТАВ И СТРУКТУРА ГРАЖДАНСКОГО ОБОРОТА
}

\begin{abstract}
АНнотАЦия. В развитие разрабатываемой автором данной статьи научной теории гражданского оборота освещаются вопросы о составе и структуре гражданского оборота. С позиций системного подхода обосновывается, что состав элементов гражданского оборота, необходимый и достаточный для функционирования последнего, образуют субъекты гражданского оборота и объекты гражданского оборота; указываются свойства каждой из указанных групп элементов. С отмеченных же методологических позиций доказывается, что в структуру гражданского оборота как реально существующего социального явления надлежит включать не только «динамические» отношения - отношения по передаче имущества (превалирующая доктринальная позиция), но и отношения «статики», отражающие принадлежность имущества. На этом основании со ссылкой на существующую правоприменительную практику делается вывод, что прогнозируемое воздействие позитивного права на систему гражданского оборота следует осуществлять в том числе посредством изменения вещно-правовых институтов.

кЛЮЧЕВЫЕ СЛОВА. Гражданский оборот; система гражданского оборота; состав гражданского оборота; субъекты гражданского оборота; объекты гражданского оборота; структура гражданского оборота; стабильность гражданского оборота; системный Подход.

ИНФОРМАЦИЯ О СТАТЬЕ. Дата поступления 4 мая 2017 г.; дата принятия к печати 18 мая 2017 г.; дата онлайн-размещения 15 июня 2017 г.
\end{abstract}

Yu. V. Vinichenko

Baikal State University,

Irkutsk, Russian Federation

\section{COMPOSITION AND STRUCTURE OF CIVIL CIRCULATION}

ABSTRACT. In developing a scientific theory of the civil circulation, the author of this article highlights the issues of composition and structure of the civil circulation. From a perspective of the system approach, the article substantiates that the composition of elements of the civil circulation, necessary and sufficient for functioning of the latter, are constituted by subjects of the civil circulation and objects of the civil circulation; it also indicates the features of each of the identifies groups of elements. The specified methodological positions prove that the structure of the civil circulation as a really existing social phenomenon should include not only the «dynamic» relations - relations of property transfer (a prevailing doctrinal position), but also the relations of «statics» that reflects the ownership of the property. On this ground with a reference to the existing law enforcement practice, a conclusion is made that the predictable impact of the positive law on the civil circulation system should be exercised, among other things, through changing the proprietary institutions.

KEYWORDS. Civil circulation; civil circulation system; composition of civil circulation; subjects of civil circulation; objects of civil circulation; structure of civil circulation; stability of civil circulation; systems approach.

ARTICLE INFO. Received May 4, 2017; accepted May 18, 2017; available online June 15, 2017.

(c) Ю. В. Виниченко, 2017

\section{Baikal Research Journal}


Введение. Данная работа направлена на развитие авторской позиции о необходимости системного восприятия явления, отображаемого в такой фундаментальной для цивилистической науки и практики категории, как «гражданский оборот» (см.: [1]). А именно она посвящена рассмотрению вопросов о составе и структуре гражданского оборота ${ }^{1}$, актуальность теоретического исследования которых усматривается в том, что их решение позволит научно обосновать потенциал позитивного права в сфере регулирования отношений, именуемых гражданским оборотом, а также определить нормы и институты позитивного права, которые способны оказывать регулирующее воздействие на гражданский оборот как реально существующее явление. Поиск ответов на данные вопросы в свою очередь необходим для реализации провозглашенной в Концепции развития гражданского законодательства $Р \Phi^{2}$ (см. п. 9 разд. I, п. 5.2.1. разд. II, п. 2.4.1 подразд. 2.4 разд. VI) и уже получившей воплощение в ряде новелл ГК $\mathrm{P}^{3}$, а также признаваемой доктриной (см., напр.: $[5, \S 3.2$. гл. 3 , с. $4 ; 6$, с. 3 ; 7 , с. $34 ; 8$, с. $104 ; 9$, с. 93]) и практикой ${ }^{4}$ идеи обеспечения стабильности гражданского оборота.

Представляется очевидным, что успешное претворение в жизнь указанной идеи невозможно без четкого осознания того, что представляет собой гражданский оборот.

Характеризуя познавательную ситуацию в данной предметной области, можно констатировать, что превалирующим в российской цивилистике является трактовка гражданского оборота как правовой формы, юридического отражения экономического оборота (см., напр.: $[10 ; 11$, с. $10 ; 12$, с. $5 ; 13$, с. $283 ; 14$, с. 3,5 и др.; 15 , с. $11 ; 16$, с. 154]). При этом вопрос о составе гражданского оборота сводится к, следует признать, неразрешимой многолетней доктринальной полемике, образует ли его некая совокупность (либо юридических фактов, либо гражданско-правовых отношений, либо фактических отношений, либо всего вышеперечисленного, либо иных явлений) или он представляет собой процесс перехода (либо субъективных прав и обязанностей, либо объектов гражданских прав, либо и объектов гражданских прав, и прав на них) (подробнее о подходах к пониманию гражданского оборота см.: [17]).

${ }^{1}$ Сразу оговоримся, что категории «состав» и «структура» мы воспринимаем как атрибуты системного подхода (среди «категориальных каркасов» которого нам наиболее близка модель, разработанная В. Н. Сагатовским) и в соответствии с этим понимаем структуру как отношения (связи) между элементами системы, а состав - как набор (перечень) таких элементов [2; 3, с. 64-67; 4, с. 89].

${ }^{2}$ Концепция развития гражданского законодательства Российской Федерации : одобр. решением Совета при Президенте РФ по кодификации и совершенствованию гражданского законодательства 7 окт. 2009 г. // Вестник Высшего Арбитражного Суда РФ. 2009. № 11.

${ }^{3}$ Пояснительная записка к проекту федерального закона «О внесении изменений в части первую, вторую, третью и четвертую Гражданского кодекса Российской Федерации, а также в отдельные законодательные акты Российской Федерации» [Электронный pecypc]. URL: http://base.consultant.ru/ cons/cgi/online.cgi?req=doc;base=PRJ;n=93951 (пояснения к ст. 173.1, гл. 10 кодекса).

${ }^{4} \mathrm{O}$ стабилизации, обеспечении стабильности гражданского оборота прямо говорится, например, в следующих судебных актах: О применении судами некоторых положений раздела I части первой Гражданского кодекса Российской Федерации : постановление Пленума Верховного Суда РФ от 23 июня 2015 г. № 25. П. 38 // Бюллетень Верховного Суда РФ. 2015. № 8 ; Постановление Президиума Высшего Арбитражного Суда РФ от 4 сент. 2007 г. № 3039/07 по делу № А40-70770/05-85579 [Электронный pecypc]. URL: http://ras.arbitr.ru/ ; Постановление Пятнадцатого арбитражного апелляционного суда от 4 марта 2016 г. № 15АП-1085/2016 по делу № A32-3757/2015 [Электронный ресурс] // Там же ; Решение арбитражного суда Астраханской области от 12 апр. 2010 г. по делу № A06-6822/2009 [Электронный ресурс] // Там же ; Решение арбитражного суда Ростовской области от 2 дек. 2010 г. по делу № А53-1583/2010 [Электронный ресурс] // Там же ; Решение арбитражного суда Кемеровской области от 8 февр. 2013 г. по делу № A27-11489/2012 [Электронный ресурс] // Там же ; Решение арбитражного суда г. Москвы от 12 нояб. 2013 г. по делу № A40-52753/2012 [Электронный ресурс] // Там же ; Решение арбитражного суда Республики Северная Осетия - Алания от 28 июля 2015 г. по делу № A61-1176/2015 [Электронный ресурс] // Там же.

\section{Baikal Research Journal}


Что касается вопроса о структуре гражданского оборота (обратим внимание, затрагиваемого учеными в контексте системологического анализа гражданского оборота), то степень его теоретической разработки емко отражает справедливое замечание А. Г. Кузнецовой о том, что «отдавая себе отчет в различии понятий “состав" и “структура", большинство исследователей, характеризуя структуру системы, на самом деле больше внимания уделяли ее составу, чем характеру связей между компонентами» [18, с. 264-265]. Так, например, М. А. Астахова, указывая на необходимость системного анализа гражданского оборота, делает вывод, что «в структурнол (здесь и далее курсив наш. - Ю. В.) плане оборот может рассматриваться как системное явление, к внешним составным элелентал которого относятся его объекты и субъекты, а к внутренним - содержание» [12, с. 2]. Аналогичным образом В. А. Петрушкин, обращаясь к вопросу о структуре гражданского оборота при рассмотрении системы оборота недвижимости, отмечает, что «в самом общем виде указанная структура включает»: 1) участников, 2) объекты и $3)$ собственные условия гражданского оборота $[19$, с. 26]. Исходя из отмеченного выше общепризнанного в системном подходе понимания структуры как связи между элементами системы, а состава как набора (перечня) таких элементов, приведенные примеры позволяют заключить, что четкого разграничения между категориями «состав гражданского оборота» и «структура гражданского оборота» в литературе не проводится. Как следствие, несмотря на использование цивилистами соответствующей терминологии, действительно разработанным и решенным вопрос о структуре гражданского оборота признать нельзя.

Между тем, по авторитетному замечанию М. С. Кагана, «без выявления структуры любой из систем самое детальное описание ее элементного состава не принесет нам знания ни природы данной системы, ни закономерности ее поведения, ни ее движения и развития" [4, с. 104]. Применительно к настоящему исследованию это означает, что только научно обоснованно выявив структуру системы гражданского оборота, можно реально прогнозировать, а не просто предполагать и «угадывать» как варианты развития самой этой системы, так и направления воздействия на нее позитивного права.

В то же время структура любой системы не может быть выявлена без определения набора составляющих ее элементов (состава), который в свою очередь детерминирован решением основополагающего при системном подходе вопроса о цели системы. Ранее мы пришли к выводу, что цель существования (предназначенность) системы гражданского оборота, поставленная перед ней вышестоящей системой общества (подсистемой которой выступает система гражданского оборота), состоит в опосредовании удовлетворения имущественных потребностей отдельных членов социума, а также в перераспределении имеющихся в обществе благ, обладающих потребительной стоимостью [1].

Состав системы гражданского оборота. Исходя из обозначенных целей системы гражданского оборота, ее состав, достаточный и необходимый для функционирования рассматриваемой системы (см.: [20, с. 37; 21, с. 27-28]), полагаем, образуют две группы элементов: 1) субъекты гражданского оборота, для удовлетворения потребностей которых в обществе возник и существует гражданский оборот; 2) объекты гражданского оборота, за счет которых и удовлетворяются потребности субъектов (в связи с чем невключение их в состав системы гражданского оборота сделает невозможным выполнение данной системой ее функций).

Каждая из указанных групп состава системы гражданского оборота может включать бесконечное множество элементов. При этом для достижения гражданским оборотом целей его существования достаточно и минимально необходимо

\section{Baikal Research Journal}


наличие двух субъектов (условно обозначим их «субъект № 1 » и «субъект № N. (где $\mathrm{N}>1$ ), допуская тем самым отмеченное бесконечное количественное «наращивание» элементов данной группы) и хотя бы одного оборотоспособного объекта (впрочем, так же как и субъектов, элементов данной группы может быть бесконечное множество).

Наличие иных, кроме указанных компонентов в составе системы гражданского оборота не является необходимым в силу присущих им свойств.

В качестве субъектов системы гражданского оборота могут выступать как отдельные физические лица, так и их объединения (группы): юридические лица, публично-правовые образования (РФ, субъекты РФ, муниципальные образования), участники гражданско-правовых сообществ (в смысле п. 2 ст. 181.1 ГК РФ). Однако забегая вперед, следует отметить, что с позиций структуры системы подобная множественность субъектов является безразличной: в обороте указанные коллективные образования выступают как один субъект, причем элементом собственно внутрисистемной связи, образующей гражданский оборот, выступает конкретное физическое лицо, «олицетворяющее» данное коллективное образование. Исходя из этого, характеристика субъектов гражданского оборота сводится к вопросу о свойствах физических лиц.

Общепризнанным в различных отраслях современной науки, изучающих человека (таких «человековедческих науках" ${ }^{5}$, как философия, социология, психология, педагогика и др.), является положение о том, что человеческая личность может рассматривать как структурная целостность биогенных, психогенных и социогенных составляющих, на основании чего выделяют биологическую, психологическую и социальную структуру личности (см., напр.: [23, с. $173 ; 24$, с. 18 ; 25 , с. 7]). Принимая во внимание, что психологические качества личности могут быть как биологически, так и социально обусловленными, полагаем необходимым деление свойств субъектов как элементов системы гражданского оборота только на две группы $\left.{ }^{6}: 1\right)$ антропологические - биологические, природные (врожденные) свойства; 2) социальные свойства, приобретаемые субъектами вследствие жизни в обществе и характеризующие их как членов социума. Значение подобной градации усматривается в том, что она позволяет определить возможные направления норлативно-правового воздействия на субъектов гражданского оборота: представляется, что такому воздействию объективно подвержены исключительно соииальные, но не антропологические свойства субъектов.

К антропологическим свойствал субъектов гражданского оборота, на наш взгляд, в частности, относятся:

- наличие потребностей - свойство субъекта, в котором выражается его отношение к необходимым условиям существования (см.: [27, с. 308]); «состояние организма, человеческой личности, социальной группы, общества в целом, выражающее зависимость от объективного содержания условий их существования и развития и выступающее источником различных форм их активности» ${ }^{7}$. При этом речь идет, прежде всего, о так называемых первичных потребностях (именуемых также «низшими», «биогенными», «естественными», «потребностями первой

${ }^{5}$ Выражение М. С. Кагана [22, с. 316].

${ }^{6}$ Это вытекает из такого необходимого логического требования, предъявляемого к делению понятий, согласно которому члены деления должны быть несовместимыми друг с другом понятиями, в противном случае объемы членов деления будут иметь общие элементы - станут совместимыми понятиями [26, с. 23].

7 Философская энциклопедия [Электронный ресурc]. URL: http://dic.academic.ru/dic.nsf/enc philosophy/7110/ПОТРЕБНОСТЬ.

\section{Baikal Research Journal}


группы» $)^{8}$, удовлетворение которых важно для функционирования человеческого организма, для сохранения человека как вида (это потребности в продуктах питания, одежде, жилище и т. п.).

- разумность как познавательная способность физических лиц, непосредственно участвующих в гражданском обороте, адекватно воспринимать окружающую действительность, понимать связь вещей и явлений и действовать целесообразно этой связи [29, с. 18]. По существу, данная способность представляет собой потенциальную способность субъекта к волевому действованию (потенциальную деятельностную активность, потенциальную волевую деятельность). Указанное свойство непосредственно и неразрывно связано с предыдущим, исходя из того, что без деятельности человека ${ }^{9}$ (в социологии и философии соотносимой с его активностью [22, с. $39 ; 23$, с. 169]) невозможно удовлетворение его потребностей, а именно волевая, суть, сознательная деятельность выделяет человека из всех представителей живой природы.

Однако разумность как познавательная способность является лишь, повторим, потенциальной деятельностной активностью субъектов. Для фактического удовлетворения потребностей субъекта это свойство должно реализоваться ${ }^{10}$. Реализуясь, оно трансформируется в актуальную (реальную) волевую деятельность, которая и влечет возникновение внутрисистемной связи между элементами системы гражданского оборота. Подобное понимание исключает необходимость выделения в составе системы гражданского оборота отдельного (самостоятельного) «связепорождающего» элемента, который с позиций традиционных правовых представлений соотносился бы с категорией юридических фактов, выступающих основаниями возникновения, изменения и прекращения правоотношения как юридической связи субъектов. В частности, действия при системном подходе к пониманию гражданского оборота являются ничем иным как функционированием субъектов как элементов данной системы, заключающемся в проявлении (реализации) ими рассматриваемого свойства разумности (потенциальной волевой деятельностной). Факты-события, бесспорно, оказывают влияние на систему гражданского оборота, внося в него флуктуацию (момент случайности), свойственную всем социальным системам, однако они находятся за познавательными (мыслимыми) границами системы гражданского оборота, относятся к ее внешней среде, вследствие чего в состав рассматриваемой системы не входят.

В числе социальных свойств субъектов как элементов системы гражданского оборота полагаем необходимым выделять:

- социальное сознание, т. е. осознание индивидом себя частью взаимосвязанной общности людей [31]. Социологами данная категория используется для фиксирования эмпирических форм реального сознания людей. При этом отмечается, что, с одной стороны, социальное сознание порождается и ограничивается специфическими свойствами социального, сущность которого понимается как «результат взаимодействия людей, оказывающий влияние на поведение других людей», а с другой стороны, «состоит из тех представлений, установок, ценностей и т. д., которые являются... интерсубъективными относительно различных социальных субъектов и групп» [32, с. 9]. Иными словами, в социальном сознании отражают-

${ }^{8}$ В числе которых ученые выделяют, в частности: физиологические потребности и потребность в безопасности (А. Маслоу), потребность в самосохранении и, отдельно, - потребность в сохранении вида (К. Обуховский), потребность в самосохранении и безопасности (С. Б. Каверин) (общий обзор имеющихся подходов см., напр.: [28]).

${ }^{9}$ Воспринимаемой как способ существования человека [22, с. 5].

${ }^{10}$ А проявиться разумность может только в действии, и только будучи выраженной вовне, она может быть оценена: «Мы отличаем помешанного от вполне разумного и обоих от ребенка; мы оцениваем меру и вид их разума по действиям», - отмечал И. Ф. Гербарт [30, с. 622-628].

\section{Baikal Research Journal}

электронный научный журнал Байкальского государственного университета 
ся ценностные установки общества, которые трансформируются в персональные ценностные качества субъектов, т. е. сформированные у них под влиянием социума этические (справедливость), морально-нравственные (честность, добросовестность) и иные личностные свойства. Уровень социального сознания у разных субъектов, равно как и у одного субъекта в разные периоды его жизни различен (при этом переход на новый уровень сопровождается трансформационными сдвигами мировоззрения [см.: 31]). Так или иначе, на настоящем этапе общественного развития социальное сознание присуще всем членам общества.

- индивидуализирующие признаки (в частности, имя, место жительства).

Основными свойствами объектов гражданского оборота являются:

- потребительная стоимость, т. е. совокупность полезных свойств объекта, благодаря которым он обладает способностью удовлетворять какую-либо потребность общества или отдельного субъекта. При этом в экономике признано, что стоимость удовлетворяет потребности не того, кто создает объект (товар), а потребности других людей, вследствие чего является общественной потребительной стоимостью, которая «интересует производителя лишь в своей взаимосвязи со способностью данного товара обмениваться на другие его виды. Это особое качество товара, в свою очередь, получило название меновой стоимости, являющейся формой стоимости, ее внешним проявлением в акте обмена» [33, с. 671].

- оборотоспособность, которую, полагаем, следует понимать как естественное свойство объекта быть предметом гражданского оборота и, таким образом, в зависимости от наличия либо отсутствия у определенного объекта данного свойства классифицировать объекты гражданских прав не на свободные в обороте, ограниченные в обороте и изъятые из оборота (как это принято в отечественной цивилистике), а на оборотоспособные и необоротоспособные объекты. Очевидно, что в качестве элементов системы гражданского оборота могут выступать только оборотоспособные объекты.

Именно коррелирующий, взаимопредполагающий характер элементов системы гражданского оборота и их свойств, а именно наличия потребностей у субъектов и потребительной стоимости у объектов, генетически обусловливает их объединение, взаимодействие, которое, выступая в качестве системообразующего фактора, и образует в итоге систему гражданского оборота.

Структура системы гражданского оборота. Исходя из состава системы гражданского оборота и учитывая ее бытийственную социальную природу, следует заключить, что ее структуру образуют фактические (реальные, жизненные) отношения, связывающие воедино субъектов и объекты как элементы данной системы (условно обозначим их $S_{1}, S_{n}, O_{1}, O_{n}$, где $S_{1}, S_{n}$ - «субъекты гражданского оборота», $O_{1}, O_{n}-$ «объекты гражданского оборота»).

В теории системного подхода является признанным, что каждый элемент системы непосредственно или опосредованно связан с каждым иным элементом. Таким образом, помимо прочего, признается наличие не только прямых, но и косвенных связей (отношений) между элементами. Кроме этого, согласно одному из общесистемологических постулатов, структура системы должна выражать всю полноту связей между компонентами последней, а не ту или иную часть этих связей, хотя бы и весьма существенных, поскольку именно полнота связей между компонентами определенной системы обеспечивает само существование, а значит, и функционирование этой системы (см.: $[4$, с. 90, 93]).

На этом основании следует признать необходимым включение в структуру системы гражданского оборота не только «динамических» отношений, т. е. таких, которые связаны с переходом благ и (или) прав на них (такова превалирующая в отечественной цивилистике трактовка гражданского оборота), но и отношений

\section{Baikal Research Journal}

электронный научный журнал Байкальского государственного университета 
«статики», отражающих принадлежность имущества. Без включения последних в структуру системы гражданского оборота она будет неполной; (опосредованная) связь, выражающая удовлетворение имущественной потребности определенного субъекта за счет «чужого» объекта не возникнет, ввиду чего функционирование данной системы окажется невозможным. Отношения принадлежности являются не просто предпосылкой, но неотъеллемой частью структуры системы гражданского оборота, т. е. самого гражданского оборота как социального феномена. Без «привязки» определенного (конкретного) объекта к отдельному (конкретному) субъекту, суть, отношений «статики», гражданский оборот невозможен ${ }^{11}$.

Для наглядности восприятия данного положения представим структуру системы гражданского оборота (ее базовые блоки) схематически.

Очевидно, что некое благо должно быть связано с его обладателем непосредственно, равно как и то, что другой субъект может получить доступ к этому благу и удовлетворить за счет него свою потребность только через отношение с его обладателем, которое в свою очередь, по общему правилу, возможно при обоюдной реальной (а не потенциальной) активности субъектов ${ }^{12}$. Схематически это можно представить следующим образом: $O_{1} \rightarrow S_{1} \leftrightarrow S_{n}$ (схема 1$)$, где « $\rightarrow$ - связь-принадлежность, «↔» - взаимная связь элементов.

Из приведенной схемы следует, что связь-принадлежность («объект № 1 субъект № 1») и связь субъектов имеют непосредственный (прямой) характер (прямую встречную по направленности связь можно назвать взаимной), в то время как связь «объект № 1 - субъект № N》 является опосредованной (косвенной), поскольку представляет собой «цепочку» отношений $\left(O_{1} \rightarrow S_{1}\right.$ и $\left.S_{1} \leftrightarrow S_{n}\right)$, лишь одним звеном которой является связь субъектов.

Из этого вытекает и то, что связь-принадлежность «объект № 1- субъект № Nㅡ $\left(O_{1} \rightarrow S_{n}\right)$ может возникнуть лишь в случае наличия связи «объект № $1-$ субъект № 1 » $\left(O_{1} \rightarrow S_{1}\right)$; в ее отсутствии (если нет одного из «связываемых» элементов) либо порочности (с точки зрения позитивного права, например, отсутствие зарегистрированного права собственности на недвижимость), даже при наличии отношения $S_{1} \leftrightarrow S_{n}$, связь «объект № $1-$ субъект № N》 не возникнет, ввиду чего функционирование данной системы окажется невозможным. Неуправомоченное отчуждение «чужого» имущества с точки зрения структуры системы гражданского оборота является примером нарушения необходимой последовательности («цепочки») связей элементов данной системы, следствием чего является «разрыв» этой «цепочки», объективно делающий невозможным ее продолжение (дальнейший оборот объекта).

Если имеет место встречное предоставление (обмен), то приведенную схему следует дополнить: $O_{1} \rightarrow S_{1} \leftrightarrow S_{n} \leftarrow O_{n}$ (схема 2), где «Ł» также отображает связь-принадлежность.

Типы дополнительно возникающих при этом отношений в основном будут идентичными отмеченным: аналогично отношению $O_{1} \rightarrow S_{1}$, связь $S_{n} \leftarrow O_{n}$ (или $\mathrm{O}_{2} \rightarrow S_{n}$ ) будет являться прямой, а связь $S_{1} \leftarrow O_{n}$ (или $O_{n} \rightarrow S_{1}$ ), подобно $O_{1} \rightarrow S_{n},-$

${ }^{11} \mathrm{C}$ точки зрения права данный вывод подтверждается наличием института выморочного имущества, а также действующей презумпцией государственной собственности на отдельные социально значимые виды бесхозяйного (бессубъектного) имущества. Включение в гражданский оборот отношений «статики» признается и отдельными учеными. Так, В. А. Петрушкин отмечает в данной связи, что «в целях обеспечения стабильности анализируемого (гражданского. - Ю. В.) оборота практически всегда учитывается фактор принадлежности того или иного имущества конкретному лицу, т. е. факт законности владения (титульное владение)», заключая: «По существу данный факт как раз подтверждает наличие "статической» составляющей в содержании категории “гражданский оборот"» [19, с. 23].

${ }^{12}$ Исключение составляет, например, наследование по закону.

\section{Baikal Research Journal}

электронный научный журнал Байкальского государственного университета 
опосредованной. Возникающая связь элементов $O_{1}$ и $O_{n}$ (объектов), так же как и отношение субъектов $\left(S_{1} \leftrightarrow S_{n}\right)$, по своей направленности будет встречной (это согласуется и с устоявшейся в правоведении терминологией - «встречное предоставление»), отличаясь косвенным характером, что не позволяет назвать ее взаимной. Косвенный характер связи объектов как элементов системы гражданского оборота, кроме прочего, указывает на то, что их потребительная стоимость может разниться и не быть абсолютно эквивалентной.

Изменение состава (появление новых либо исключение ранее существовавших элементов) системы гражданского оборота неизбежно сказывается на количестве образующих ее связей. По мере появления в составе системы новых элементов ее общая структура будет все более и более усложняться, однако типы связей отдельных элементов между собой будут оставаться неизменными, соответствуя одному из указанных выше (прямая, косвенная, встречная, взаимная связь). Этим обусловливается временна́я устойчивость структуры, а, следовательно, и всей системы гражданского оборота, поскольку, как признается в теории системного подхода, структура является стабилизирующим началом системы ${ }^{13}$.

Исходя из этого, стабильность гражданского оборота означает устойчивость составляющих данную систему связей, в том числе и даже в первую очередь (если учитывать последовательность связей в приведенной выше общей «цепочке» структуры системы гражданского оборота) - отношений принадлежности благ. Соответственно, обеспечение стабильности гражданского оборота, о котором неоднократно говорится в Концепции развития гражданского законодательства РФ, юридической литературе и материалах правоприменительной практики, заключается в создании либо поддержании условий для сохранения образующих систему гражданского оборота социальных связей, включая последовательное «развертывание» последних.

Заключение. Учитывая изложенное, возвращаясь к тезису о том, что решение вопросов о составе и структуре гражданского оборота позволит научно обосновать и определить нормы и институты позитивного права, которые способны оказывать регулирующее воздействие на гражданский оборот как социальный феномен, в числе таких норм и институтов следует выделить правила: 1) определяющие правовой статус (права и обязанности) субъектов и 2) устанавливающие правовой режим объектов.

Примечательно, что в ходе реформирования отечественного гражданского законодательства был изменен и дополнен значительный массив именно данных норм. Из числа новелл ГК РФ, касающихся субъектов как элементов системы гражданского оборота, к ним можно отнести, в частности, новые правила о дееспособности граждан (ст. 29, 30 ГК РФ), нормы о юридических лицах (гл. 4 ГК РФ). Сюда же, согласно предлагаемой концепции (рассматривающей юридические факты-действия как проявление субъектами их свойства разумности), можно причислить: легальное закрепление принципа добросовестности (ст. 1 ГК РФ); положения о пределах осуществления гражданских прав (ст. 10 ГК РФ); нормы о решениях собраний (породившие в науке в том числе вопрос о гражданско-правовом сообществе как субъекте гражданских прав) (гл. 9.1. ГК РФ); новеллы о недействительности сделки и условиях ее оспаривания, блокирующие действия субъектов, дестабилизирующие гражданский оборот (ст. 168, 166 ГК РФ); нормы о безотзывной доверенности (ст. 188.1 ГК РФ), призванной сделать более устойчивыми и предсказуемым отношения участников гражданского оборота-предпринимателей. В части объектов

13 «Структура не содержит потребности трансформации, она является, напротив, стабилизирующил началол систель (курсив наш. - Ю. В.)» [4, с. 93].

\section{Baikal Research Journal}

электронный научный журнал Байкальского государственного университета 
гражданского оборота особо выделим: новую ст. 8.1 ГК РФ о государственной регистрации прав на имущество; скорректированные правила об оборотоспособности объектов гражданских прав, не содержащие теперь указание на категорию объектов, изъятых из оборота (ст. 129 ГК РФ), равно как и сам перечень объектов гражданских прав (ст. 128, новая редакция гл. 7 ГК РФ); правила ст. 133.1 ГК РФ о новом виде недвижимых вещей - едином недвижимом комплексе; уточненные положения о неделимых и сложных вещах (ст. 133, 134 ГК РФ) и т. д.

Как видно, законодателем уже проделана колоссальная работа. Между тем комплекс мер, направленных на обеспечение стабильности гражданского оборота, полагаем, может быть расширен.

Прежде всего, в данной связи следует заметить, что все вышеперечисленные новеллы являются гражданско-правовыми. Вместе с тем, исходя из понимания гражданского оборота как подсистемы общества, включающей не только отношения, соответствующие нормативно-правовым предписаниям, но и социальные связи, сопряженные с нарушением норм позитивного права, в том числе административного и уголовного, убеждены, что воздействие на гражданский оборот должно быть комплексным, межотраслевым. Это предполагает в первую очередь унификацию понятийно-терминологического аппарата разных отраслей (в частности, интерпретацию используемых и в гражданском праве, и в отраслях публичного права понятий «оборот», «объекты, изъятые из оборота», «объекты, ограниченные в обороте»).

Устойчивости гражданского оборота, на наш взгляд, в немалой степени способствовала бы также корректировка налогового законодательства, на сегодняшний день, увы, скорее провоцирующего деформацию системы оборота - увеличение в нем скрытых теневых процессов ${ }^{14}$, с позиций юридической квалификации подпадающих под категорию обхода закона.

Однако для реализации указанных положений нужны более детальные представления о системе гражданского оборота, причем основанные не только и не столько на догматическом анализе существующих норм и конструкций, сколько на данных эмпирического опыта, в области юриспруденции (призванной способствовать реализации правом его ключевой функции - разрешения человеческих конфликтов) предстающего в более или менее верифицированном виде в судебной практике. Именно последняя со всей очевидностью свидетельствует, применительно к вопросу о структуре гражданского оборота, что стабилизация гражданского оборота достигается посредством таких правовых институтов, как институт государственной регистрации права собственности и иных вещных прав на недвижимое имущество ${ }^{15}$, институт приобретательной давности ${ }^{16}$, институт вин-

${ }^{14}$ Нам близка позиция ученых, выделяющих в теневой экономике такие относительно самостоятельные подвиды неформальной экономики (ненаблюдаемой экономической деятельности, т. е. такой, которая по тем или иным причинам не учитывается государственной статистикой, не охватывается налогообложением и не включается в ВВП), как криминальная (незаконная) экономика и скрытая (подпольная) экономика. При этом в отличие от криминальной экономики в рамках скрытой экономики обращаются блага, не ограниченные в обороте, в связи с чем ответственность наступает не за собственно оборот, а за сопутствующее этому обороту неисполнение обязательств, связанных с оборотом (уклонение от уплаты налогов, взносов и иных обязательных платежей) (см.: [34, с. 594, 604]).

${ }^{15}$ См., напр.: п. 38 постановления Пленума Верховного Суда Российской Федерации от 23 июня 2015 г. № 25 ; Кассационное определение Магаданского областного суда от 13 дек. 2011 г. № 331362/11 по делу № 2-1810/11 [Электронный ресурc]. URL: http://domovodstvo.ru/fas2/44257B060 05C4ACF44257B0200039D4A.html ; Постановление Пятого арбитражного апелляционного суда от 14 марта 2016 г. по делу № A51-13412/2015 [Электронный pecypc]. URL: http://ras.arbitr.ru/ .

${ }^{16}$ Cм., напр.: Решение Пятигорского городского суда Ставропольского края от 29 апр. 2011 г. по делу № 2-794/11 [Электронный ресурс] // URL: http://ras.arbitr.ru/.

\section{Baikal Research Journal}

электронный научный журнал Байкальского государственного университета 
дикации ${ }^{17}$, исходя из чего следует заключить, что прогнозируемое воздействие позитивного права на систему гражданского оборота следует осуществлять в том числе посредством изменения вещно-правовых институтов.

Планируемый блок законодательных изменений о вещном праве пока не принят. Оценивая предлагаемые изменения, полагаем, что будут способствовать обеспечению стабильности гражданского оборота и закрепление владения как факта, и законодательное воплощение такого признаваемого доктриной признака вещных прав, как принудительная типизация. Серьезные сомнения (и содержательно, и с позиций юридической техники), впрочем, вызывают потенциальные новеллы о так называемых соседских правах [35].

В заключение отметим, что представленные в настоящей работе взгляды и суждения не претендуют на их исчерпывающий характер и бесспорность и открыты для конструктивной критики, за которую автор статьи будет только благодарен.

\section{Список использованной литературы}

1. Виниченко Ю. В. Гражданский оборот как система / Ю. В. Виниченко // Сибирский юридический вестник. - 2015. - № 4. - С. 47-53.

2. Сагатовский В. Н. Опыт построения категориального аппарата системного подхода / В. Н. Сагатовский // Философские науки. -1976. - № 3. - С. 67-78.

3. Сагатовский В. Н. Системная деятельность и ее философское осмысление / В. Н. Сагатовский // Системные исследования. Ежегодник. 1980. - М. : Наука, 1981. - С. 52-68.

4. Каган М. С. Система и структура / М. С. Каган // Системные исследования. Ежегодник 1983. - М. : Наука, 1983. - C. 86-106.

5. Аверьянова М. В. Защита добросовестного приобретателя имущества в российском гражданском праве : дис. ... канд. юрид. наук : 12.00 .03 / М. В. Аверьянова. - М., 2001. - 215 с.

6. Желонкин С. С. Недействительность антисоциальных сделок / С. С. Желонкин. M. : Статут, 2014. - $159 \mathrm{c.}$

7. Моргунов С. В. Виндикация в гражданском праве. Теория. Проблемы. Практика / С. В. Моргунов. - М. : Статут, 2006. - 301 с.

8. Новоселова А. А. Вещные иски: проблемы теории и практики : монография / А. А. Новоселова, Т. П. Подшивалов. - М. : Инфра-М, 2014. - 279 с.

9. Райников А. С. Стабильность гражданского оборота: контуры судебной практики / А. С. Райников // Защита частных прав: проблемы теории и практики : материалы 3-й ежегод. Междунар. науч.-практ. конф. Иркутск, 19-20 сент. 2014 г. / под ред. Н. П. Асланян, Ю. В. Виниченко. - Иркутск : Изд-во БГУЭП, 2014. - С. 92-96.

10. Братусь С. Н. О понятии гражданского оборота в советском гражданском праве (доклад на заседании Сектора гражданского права Всесоюзного института юридических наук) / С. Н. Братусь // Советское государство и право. - 1949. - № 11. - С. 71-72.

11. Красавчиков О. А. Советский гражданский оборот (понятие и основные звенья) / О. А. Красавчиков // Ученые записки Саратовского юридического института. - М. : Гос. изд-во юрид. лит., 1957. - Т. V : Вопросы гражданского, трудового права и гражданского процесса. - С. 3-27.

12. Астахова М. А. Оборот в гражданском праве: понятие, структура, разновидности / М. А. Астахова // Бюллетень нотариальной практики. - 2006. - № 4. - С. 2-6.

13. Белов В. А. Гражданское право. Общая часть Т. ІІ. Лица, блага, факты : учебник / В. А. Белов. - М. : Юрайт, 2011. - 1093 с.

14. Михайлова Н. С. Оборотоспособность вещей в гражданском праве и роль актов органов внутренних дел Российской Федерации в ее реализации : автореф. дис. ... канд. юрид. наук : 12.00 .03 / Н. С. Михайлова. - СПб., 2007. - 19 с.

15. Полуяхтов И. А. Гражданский оборот имущественных прав : дис. ... канд. юрид. наук : 12.00 .03 / И. А. Полуяхтов. - Екатеринбург, 2002. - 183 с.

${ }^{17}$ См., напр.: Постановление Президиума Высшего Арбитражного Суда РФ от 4 сент. 2007 г. № 3039/07 ; Решение арбитражного суда Астраханской области от 12 апр. 2010 г. ; Решение арбитражного суда Кемеровской области от 8 февр. 2013 г. ; Решение арбитражного суда г. Москвы от 12 нояб. 2013 г.

\section{Baikal Research Journal}


16. Цветков С. Б. О сущности и понятии гражданского оборота / С. Б. Цветков // Свобода. Право. Рынок : материалы Всерос. науч. конф. «40 лет Волгоградской цивилистике», 21-22 мая 2007 г. - Волгоград : Волгогр. акад. МВД России, 2007. — Вып. 5. C. 147-154.

17. Виниченко Ю. В. «Гражданский оборот»: подходы к пониманию и их трактовка в российской цивилистике / Ю. В. Виниченко // Бизнес. Образование. Право. Вестник Волгоградского института бизнеса. - 2016. - № 1 (34). - С. 195-201.

18. Кузнецова А. Г. Развитие системного подхода в отечественной педагогике конца 60-х-80-х годов XX века : дис. ... д-ра пед. наук : 13.00.01 / А. Г. Кузнецова. - Хабаровск, 2000. - 383 c.

19. Петрушкин В. А. Системный анализ гражданско-правовой модели оборота недвижимости: проблемы теории и практики : дис. ... д-ра юрид. наук : 12.00 .03 / В. А. Петрушкин. - М., 2014. - 417 с.

20. Каган М. С. Системный подход и гуманитарное знание : избр. ст. / М. С. Каган. Л. : Изд-во Ленингр. ун-та, 1991. - 383 с.

21. Протасов В. Н. Правоотношение как система / В. Н. Протасов. - М. : Юрид. лит., 1991. - 143 c.

22. Каган М. С. Человеческая деятельность (Опыт системного анализа) / М. С. Каган. - М. : Политиздат, 1974. -328 с.

23. Социология. Основы общей теории : учеб. пособие / под ред. Г. В. Осипова, Л. Н. Москвичева. - М. : Аспект Пресс, 1996. - 461 с.

24. Лысак И. В. Философско-антропологический анализ деструктивной деятельности современного человека : автореф. дис. ... д-ра филос. наук : 09.00.13 / И. В. Лысак. — Ростов н/Д., 2007. - 48 с.

25. Селевко Г. К. Энциклопедия образовательных технологий : в 2 т. / Г. К. Селевко. - М. : НИИ шк. технологий, 2006. - Т. 2. - 816 с.

26. Корнакова С. В. Логика для юристов / С. В. Корнакова. - Иркутск : Изд-во БГУЭП, 2015. - 122 с.

27. Философия : учебник / В. Кузнецов, И. Кузнецова, В. Миронов, К. Момджян. М. : Инфра-М, 2004. $-519 \mathrm{c}$

28. Каверин С. Б. О психологической классификации потребностей [Электронный pecypc] / С. Б. Каверин. - Режим доступа: http://www.voppsy.ru/ issues $/ 1987 / 875 / 875121 . \mathrm{htm}$.

29. Виниченко Ю. В. Разумность в гражданском праве Российской Федерации : дис. ... канд. юрид. наук : 12.00.03 / Ю. В. Виниченко. - Иркутск, 2003. - 190 с.

30. Гербарт И. Ф. Введение в философию / И. Ф. Гербарт // Антология мировой философии : в 4 т. - М. : Мысль, 1971. - Т. 3. - С. 622-628.

31. Развитие социального сознания [Электронный ресурс] // Трансформация мировоззрения и развитие социального сознания / М. Шлитц, К. Витен, Э. М. Миллер. - Режим доступа : http://www.vsepsihologi.ru/articles/art-special/247-socialcon.html.

32. Константинов С. А. Устойчивость как атрибут социального сознания (на материалах исследования студенчества) : автореф. дис. ... канд. социол. наук : 22.00.06 / С. А. Константинов. - Саратов, 1994. - 16 с.

33. Большая экономическая энциклопедия / Т. П. Варламова, Н. А. Васильева, Л. М. Неганова [и др.]. - М. : Эксмо, 2007. - 816 с.

34. Быков С. С. Уголовно-правовая реакция на проявления теневой экономики: границы, характер и направления совершенствования / С. С. Быков, А. П. Киреенко, Е. Н. Невзорова // Криминологический журнал Байкальского государственного университета экономики и права. - 2015. - Т. 9, № 3. - C. 591-607. — DOI: 10.17150/19967756.2015.9(3).591-607.

35. Виниченко Ю. В. Соседское право в России: исторические начала и подходы к пониманию / Ю. В. Виниченко, Н. П. Асланян, О. А. Поротикова. - М. : Юриспруденция, 2014. - 152 c.

\section{References}

1. Vinichenko Iu. V. Civil circulation as a system. Sibirskii yuridicheskii vestnik = Siberian Legal Bulletin, 2015, no. 4, pp. 47-53. (In Russian).

\section{Baikal Research Journal}


2. Sagatovskii V. N. Experience in constructing a categorical apparatus of the system approach. Filosofskie nauki = Philosophical Sciences, 1976, no. 3, pp. 67-78. (In Russian).

3. Sagatovskii V. N. System activity and its philosophical understanding. Sistemnye issledovaniya. Ezhegodnik. 1980 [System Research. Yearbook. 1980]. Moscow, Nauka Publ., 1981, pp. 52-68. (In Russian).

4. Kagan M. S. System and Structure. Sistemnye issledovaniya. Ezhegodnik. 1983 [System Research. Yearbook. 1983]. Moscow, Nauka Publ., 1983, pp. 86-106. (In Russian).

5. Averyanova M. V. Zashchita dobrosovestnogo priobretatelya imushchestva $v$ rossiiskom grazhdanskom prave. Kand. Diss. [Protection of bone fide purchaser of property in the Russian Civil Law. Cand. Diss.]. Moscow, 2001. 215 p.

6. Zhelonkin S. S. Nedeistvitel'nost' antisotsial'nykh sdelok [Invalidy of antisocial transactions]. Moscow, Statut Publ., 2014. 159 p.

7. Morgunov S. V. Vindikatsiya $v$ grazhdanskom prave. Teoriya. Problemy. Praktika [Vindication in Civil Law. Theory. Problems. Practice]. Moscow, Statut Publ., 2006. 301 p.

8. Novoselova A. A., Podshivalov T. P. Veshchnye iski: problemy teorii i praktiki [Things-in-possession lawsuits: problems of theory and practice]. Moscow, Infra-M Publ., 2014. 279 p.

9. Rainikov A. S. Stability of civil turnover: the contours of judicial practice. In Aslanyan N. P., Vinichenko Yu. V. (eds). Zashhita chastnykh prav: problemy teorii i praktiki. Materialy 3-i Mezhdunarodnoi nauchno-prakticheskoi konferentsii. Irkutsk, 19-20 sentyabrya 2014 g. [Protection of Private Rights: Problems of Theory and Practice. Materials of the 3-rd International Research Conference. Irkutsk, September 19-20, 2014]. Irkutsk, Baikal State University of Economics and Law Publ., 2014, pp. 92-96. (In Russian).

10. Bratus S. N. On the concept of civil turnover in the Soviet Civil Law (a report at the meeting of the Civil Law Sector of All-Union Institute of Juridical Sciences). Sovetskoe gosudarstvo $i$ pravo $=$ Soviet State and Law, 1949, no. 11, pp. 70-72. (In Russian).

11. Krasavchikov O. A. Soviet civil turnover (concept and main links). Uchenye zapiski Saratovskogo yuridicheskogo instituta [Scholarly Notes of Saratov State University]. Moscow, Gosyurizdat Publ., 1957, vol. 5, pp. 3-27. (In Russian).

12. Astakhova M. A. Circulation in civil law: concept, structure, types. Byulleten' notarial'noi praktiki = Bulletin of Notarial Practice, 2006, no. 4, pp. 2-6. (In Russian).

13. Belov V. A. Grazhdanskoe pravo. Obshhaya chast [Civil Law. General Part]. Moscow, Yurait Publ., 2011. Pr. 2. 1093 p.

14. Mikhailova N. S. Oborotosposobnost' veshchei $v$ grazhdanskom prave i rol' aktov organov vnutrennikh del Rossiiskoi Federatsii v ee realizatsii. Avtoref. Kand. Diss. [Circulability of properties in Civil Law and role of acts of internal affairs bodies of the Russian Federation in its implementation. Cand. Diss. Thesis]. Saint Petersburg, 2007. 19 p.

15. Poluyakhtov I. A. Grazhdanskiy oborot imushhestvennykh prav. Kand. Diss. [Civil Turnover of Property Rights. Cand. Diss.]. Yekaterinburg, 2002. 183 p.

16. Tsvetkov S. B. On essence and concept of the civil circulation. Svoboda. Pravo. Rynok. Materialy Vserossiiskoi nauchnoi konferentsii "40 let Volgogradskoi tsivilistike», 21-22 maya 2007 g. [Freedom. Law. Market. Materials of All-Russian Research Conference, May 21-22, 2007]. Volgograd Academy of Russian Internal Affairs Ministry Publ., 2007, iss. 5, pp. 147-154. (In Russian).

17. Vinichenko Yu. V. «Civil circulation»: approaches to understanding and their interpretation in the Russian Civil Law. Biznes. Obrazovanie. Pravo. Vestnik Volgogradskogo instituta biznesa = Business. Education. Law. Bulletin of Volgograd Business Institute, 2016, no. 1 (34), pp. 195-201. (In Russian).

18. Kuznetsova A. G. Razvitie sistemnogo podkhoda $v$ otechestvennoi pedagogike kontsa 60-kh-80-kh godov XX veka. Dokt. Diss. [System approach development in national pedagogics in late 60-80-s of XX-th century . Doct. Diss.]. Khabarovsk, 2000. 383 p.

19. Petrushkin V. A. Sistemnyi analiz grazhdansko-pravovoi modeli oborota nedvizhimosti: problemy teorii i praktiki. Dokt. Diss. [System analysis of the civil-legal model of turnover of immovable property: problems of theory and practice. Doct. Diss.]. Moscow, 2014. $417 \mathrm{p}$.

20. Kagan M. S. Sistemnyi podkhod i gumanitarnoe znanie [System Approach and Humanitarian Knowledge]. Leningrad State University Publ., 1991. 383 p.

21. Protasov V. N. Pravootnoshenie kak sistema [A Legal Relation as a System]. Moscow, Yuridicheskaya literature Publ., 1991. 143 p.

\section{Baikal Research Journal}


22. Kagan M. S. Chelovecheskaya deyatel'nost' (Opyt sistemnogo analiza) [Human activity (experience of system analysis)]. Moscow, Politizdat Publ., 1974. 328 p.

23. Osipov G. V., Moskvichev L. N., Kabyshcha A. V. et al. Sotsiologiya. Osnovy obshchei teorii [Sociology. Basics of General Theory]. Moscow, Aspekt Press, 1996. $461 \mathrm{p}$.

24. Lysak I. V. Filosofsko-antropologicheskii analiz destruktivnoi deyatel'nosti sovremennogo cheloveka. Avtoref. Dokt. Diss. [Philosophical and anthropological analysis of destructive activity of modern human. Doct. Diss. Thesis]. Rostov-on-Don, 2007. 48 p.

25. Selevko G. K. Entsiklopediya obrazovatel'nykh tekhnologii [Encyclopedia of Educational Technologies]. Moscow, Research Institute of School Technologies, 2006. Vol. 2. 816 p.

26. Kornakova S. V. Logika dlya yuristov [Logics for Lawyers].Irkutsk, Baikal State University of Economics and Law Publ., 2015. 122 p.

27. Kuznetsov V., Kuznetsova I., Mironov V., Momdzhyan K. Filosofiya [Philosophy]. Moscow, Infra-M Publ., 2004. 519 p.

28. Kaverin S. B. O psikhologicheskoi klassifikatsii potrebnostei [On psychological classification of needs. Available at: http://www.voppsy.ru/issues/1987/875/875121.htm. (In Russian).

29. Vinichenko Yu. V. Razumnost' $v$ rossiiskom grazhdanskom prave. Kand. Diss. [Reasonableness in the Russian Civil Law. Cand. Diss.]. Irkutsk, 2003. 190 p.

30. Gerbart I. F. Introduction into Philosophy. Antologiya mirovoi filosofii [Anthology of World Philosophy]. Moscow, Mysl' Publ., 1971, vol. 3, pp. 622-628. (In Russian).

31. Development of social consciousness. In Shlitts M., Viten K., Miller E. M. Transformatsiya mirovozzreniya $i$ razvitie sotsial'nogo soznaniya [Transformation of the outlook and development of the social consciousness]. Available at: http://www.vsepsihologi.ru/articles/ art-special/247-socialcon.html. (In Russian).

32. Konstantinov S. A. Ustoichivost' kak atribut sotsial'nogo soznaniya (na materialakh issledovaniya studenchestva). Avtoref. Kand. Diss. [Stability as an attribute of social consciousness (a case study of investigating student community). Cand. Diss. Thesis]. Saratov, 1994. 16 p.

33. Varlamova T. P., Vasil'eva N. A., Neganova L. M. et al. Bol'shaya ekonomicheskaya entsiklopediya [The Great Economic Encyclopedia]. Moscow, Eksmo Publ., 2007. 816 p.

34. Bykov S. S., Kireyenko A. P., Nevzorova E. N. c Response of criminal law to shadow economy: borders, character and areas for improvement. Criminology Journal of Baikal National University of Economics and Law, 2015, vol. 9, no. 3, pp. 591-607. DOI: 10.17150/19967756.2015.9(3).591-607. (In Russian).

35. Vinichenko Yu. V., Aslanyan N. P., Porotikova O. A. Sosedskoe pravo v Rossii: istoricheskie nachala $i$ podkhody $k$ ponimaniyu [Neighboring Law in Russia: Historical Beginning and Approaches to Understanding]. Moscow, Yurisprudentsiya Publ., 2014. 152 p.

\section{Информация об авторе}

Виниченко Юлия Вараздатовна - кандидат юридических наук, доцент, заведующий кафедрой гражданского права и процесса, Байкальский государственный университет, 664003, г. Иркутск, ул. Ленина, 11, e-mail: juvinichenko@mail.ru.

\section{Author}

Yuliya V. Vinichenko - PhD in Law, Associate Professor, Head of Chair of Civil Law and Procedure, Baikal State University, 11 Lenin St., 664003, Irkutsk, Russian Federation; e-mail: juvinichenko@mail.ru.

\section{Библиографическое описание статьи}

Виниченко Ю. В. Состав и структура гражданского оборота / Ю. В. Виниченко // Baikal Research Journal. - 2017. — T. 8, № 2. — DOI: 10.17150/2411-6262.2017.8(2).3.

\section{Reference to article}

Vinichenko Yu. V. Composition and structure of civil circulation. Baikal Research Journal, 2017, vol. 8, no. 2. DOI: 10.17150/2411-6262.2017.8(2).3. (In Russian).

\section{Baikal Research Journal}

